\title{
PENERAPAN LOGIKA FUZZY PADA SISTEM MONITORING DAN KONTROL KANDANG AYAM OTOMATIS BERBASIS IoT
}

\author{
Putu Adi S, Agung Panji Sasmito, Renaldi Primaswara \\ Program Studi Teknik Informatika S1, Fakultas Teknologi Industri \\ Institut Teknologi Nasional Malang, Jalan Raya Karanglo km 2 Malang, Indonesia \\ 1718062@scholar.itn.id
}

\begin{abstract}
ABSTRAK
Penelitian ini bertujuan untuk mengembangkan alat yang dapat membantu peternak ayam memonitoring dan menjaga suhu, kelembaban, gas ammonia, dan sisa pakan. Pada penelitian ini menggunakan sesnsor DHT22 untuk mendeteksi suhu dan kelembaban, dan sensor MQ137 untuk mendeteksi gas ammonia, dan sensor ultrasonik digunakan untuk mendeteksi sisa pakan ayam. Fuzzy yang digunakan dalam penelitian ini adalah fuzzy Mamdani Penerapan logika fuzzy yang digunakan untuk memantau suhu dan kelembaban kandang ayam pada penelitian ini ditempatkan pada source code arduino yang akan mengeluarkan keluaran sesuai dengan aturan atau aturan yang telah ditentukan. Hasil dari penelitian ini berupa alat monitoring dan control otomatis untuk para peternak ayam berbasis IoT. Alat ini dapat bekerja dengan baik, dilihat dari real time antara alat yang digunakan dengan data yang dihasilakan sehingga ketika suhu, kelembaban, gas ammonia, dan sisa pakan ada perubahan maka akan langsung terdeteksi oleh alat.
\end{abstract}

Kata Kunci : Sistem monitoring, Fuzzy, sensor MQ137 gas amonia

\section{PENDAHULUAN}

Industri pembibitan berkembang sangat pesat, dan ada permintaan yang tinggi untuk peternak unggas seperti ayam pedaging. Peternakan unggas mencakup semua proses peternakan unggas untuk daging. Broiler merupakan ras murni yang tumbuh cepat, sehingga dapat menghasilkan daging dalam waktu yang relatif singkat (5-7 minggu). Kandang adalah bagian dari manajemen broiler Perhatian khusus harus diberikan pada kadar amonia, suhu udara dan kelembaban.

Resiko kematian yang tinggi disebabkan karena kondisi kendang yang kurang perhatian sehingga suhu, kelembaban dan gas ammonia yang tinggi, (Kurnia, 2017) faktanya di daerah tropis seperti di dusun batu ringgit, kecamatan gangga, KLU yang daerahnya pegunungan yang mamang memiliki suhu dan kelembaban yang tinggi sehingga berdampak pada kondisi ayam yang mudah stress dan mudah terserang penyakit dan gangguan pertumbuhan. Dalam perkembangan teknologi yang sangat pesat saat ini, banyak perkembangan ini dapat dilihat dari teknologi mikrokontroler yang merupakan suatu terobosan teknologi mikroprosessor dan mikrokomputer, hal ini sangat membantu peternak ayam broiler,dengan adanya sensor yang digunakan untuk penerapan ini yaitu sensor DHT 22 untuk mendeteksi suhu dan kelembaban pada kendang ayam, dan sensor $M Q 137$ Nh3 digunakan untuk mendeteksi gas ammonia, lampu pemanas $40 \mathrm{w}$ untuk meningkatkan suhu pada kendang ayam, dan kipas input digunakan untuk mendinginkan kandang ayam, dan kipas output digunakan untuk mengeluarkan gas ammonia dan nantinya semua sensor akan dimonitoring melalui website yang sudah dihubungkan dengan NodeMCU. Berdasarkan paparan tersebut di atas diketahui bahwa sejauh ini monitoring yang dilaksanakan dalam
Peneliti menggagas adanya sistem monitoring ayam dengan menggunakan IoT dengan sensor DHT22, Sensor MQ137 dan Sensor ultrasonic yang diharapkan dapat membantu peternak dalam meningkatkan hasil panen.

\section{TINJAUAN PUSTAKA}

\subsection{Penelitian Terdahulu}

Maghfiroh (2018), dalam penelitian selanjutnya yang berjudul "Efektivitas Sistem Informasi Laporan Pemantauan dan Evaluasi (Pengendalian Elektronik) Seksi Evaluasi Pembangunan Setda Bontang”. Tujuan penelitian ini adalah untuk menganalisis efektivitas sistem informasi pelaporan monitoring dan evaluasi (pengendalian) pada bagian evaluasi pembangunan Sekretariat Daerah Kota Bontang, dilanjutkan dengan analisis faktor pendukung dan penghambat dalam efektivitas monitoring dan evaluasi. Sistem Informasi Pelaporan (Electronic Control) sedang dikembangkan oleh Seksi Evaluasi Setda Kota Bondang [1]

Priyanto (2015) melakukan penelitian berjudul "Sistem Informasi Monitoring Perkuliahan Berbasis Web di STMIK Sinar Nusantara Surakarta". Tujuan dari penelitian ini adalah untuk memungkinkan lebih banyak kontrol dan pembaruan selama pelaksanaan pemantauan pidato, karena melibatkan entitas eksternal yang terhubung dalam sistem. Sistem informasi pemantauan ucapan memiliki beberapa kesamaan dengan konten yang dibuat oleh penulis. [2]

Selain itu, dalam makalah Wibowo (2019), topik penelitiannya adalah "Ruang Kuliah Pintar Pemantau Tingkat Efektivitas Pembelajaran Yang Dapat Mendeteksi Mahasiswa Bosan Dan Mengantuk", dan tujuannya adalah untuk mengaplikasikan teknologi Internet of Things (IoT) pada tampilan status menggunakan RFID This Teknologi memungkinkan 
guru, administrator, orang tua dan siswa untuk melihat data kehadiran secara real time dan online. Dengan cara ini, jika siswa tidak berada di kelas, orang tua dapat dengan cepat mendeteksi keberadaan mereka melalui pengenalan wajah, dan mengevaluasi keefektifan pembelajaran melalui pengenalan wajah dan deteksi batuk siswa. Jika proses pembelajaran tidak tepat, perbaikan dapat dilakukan untuk menangani sistem pembelajaran dengan lebih optimal. [3]

Terakhir, ada makalah oleh Risnandar (2015) tentang penelitian selanjutnya yang berjudul "Pembuatan Aplikasi Sistem Informasi Monitoring Kegiatan Mahasiswa Berbasis Web dan Android Client". Tujuan dari penelitian ini adalah untuk memantau aktivitas siswa. [4]

\subsection{Arduino Uno Robotdyn}

Arduino Uno Robotdyn adalah papan mikrokontroler berbasis ATmega328P + ESP8266 (lembar data). Memiliki 14 pin input dari output digital, 6 di antaranya dapat digunakan sebagai output PWM, dan 6 pin input analog, 16 di antaranya dari ESP8266, dan terdapat 5 pin GPIO. Memiliki memori flash 8MB, USB-TTL CH340G, dan menggunakan Micro-USB untuk memprogramnya (sumber: Putu Adi Sudarmawan).

\subsection{Sensor MQ137 (Gas Amonia)}

Sensor MQ 137 adalah sensor sensitif yang terbuat dari bahan $\mathrm{SnO} 2$. Konduktivitasnya rendah di udara bersih, dan konduktivitasnya meningkat seiring dengan peningkatan konsentrasi gas yang terdeteksi. untuk perubahan konduktivitas sesuai dengan konsentrasi gas yang digunakan di rangkaian sederhana. Karakteristik sensor MQ 137 sangat sensitif terhadap amonia, (Heriawan, 2017 : https://text-id.123dok.com) (Heriawan, 2012)

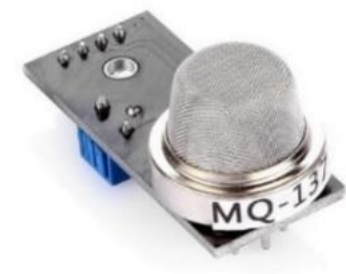

Gambar 1 Sensor $M Q 137$

(sumber: https://www. sainsmart.com)

\subsection{Sensor Ultrasonik HC-SR04}

Sensor ultrasonik adalah sensor yang digunakan untuk mengubah besaran fisik (suara) menjadi listrik dan sebaliknya. Metode kerja sensor didasarkan pada prinsip pantulan gelombang suara, sehingga dapat digunakan untuk menjelaskan keberadaan (jarak) suatu benda dengan frekuensi tertentu. Disebut sensor ultrasonik karena menggunakan gelombang ultrasonik (gelombang ultrasonik). (ElangSakti, 2015)

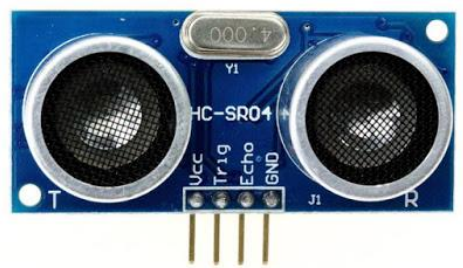

Gambar 2 Sensor Ultrasonik HC-SRO4

(sumber: https://www.elangsakti.com/)

\subsection{IoT (Internet Of Thing)}

Internet of Things adalah konsep di mana objek tertentu memiliki kemampuan untuk mengirimkan data melalui jaringan tanpa interaksi manusia-ke-manusia atau manusia-komputer. Internet of Things sering disebut Internet of Things. Berawal dari integrasi teknologi nirkabel, sistem mikroelektromekanis (MEMS) dan Internet, Internet of Things telah berkembang pesat. (Dewaweb, 2018: https://www.dewaweb.com) (dewaweb, 2018)

\subsection{Pengertian DHT22}

DHT-22 atau AM2302 adalah sensor suhu dan kelembaban yang memiliki keluaran berupa sinyal digital yang diubah dan dihitung oleh MCU 8-bit terintegrasi. Sensor dikalibrasi secara akurat melalui penyesuaian kompensasi suhu ruangan, dan nilai koefisien disimpan dalam memori OTP terintegrasi. (AMRULLAH, 2017)

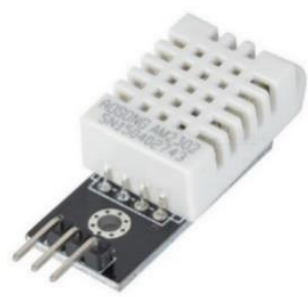

Gambar 3 DHT22

(sumber: http://tokoteknologi.co.id/)

\subsection{Relay}

Relai adalah sakelar yang dioperasikan secara elektrik, sebuah komponen elektromekanis, terdiri dari dua bagian utama, yaitu elektromagnet (koil) dan bagian mekanis (sekumpulan kontak sakelar), seperti yang ditunjukkan pada Gambar 2.4. (kho, n.d.)

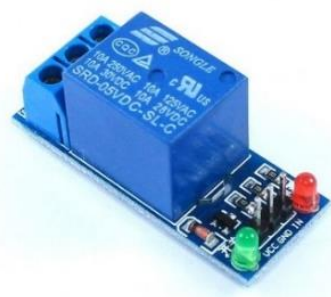

Gambar 4 Relay

(sumber: https://sg.cytron.iol 


\subsection{Logika Fuzzy}

Logika fuzzy merupakan salah satu komponen soft computing. Logika fuzzy pertama kali dikenalkan oleh Professor. Lotfi A. Zadeh pada tahun 1965. Dasar dari logika fuzzy adalah teori himpunan fuzzy. Dalam teori himpunan fuzzy, derajat keanggotaan merupakan faktor penting untuk menentukan keberadaan elemen dalam himpunan. Nilai derajat keanggotaan atau derajat keanggotaan atau derajat fungsi keanggotaan merupakan ciri utama penggunaan logika fuzzy ini untuk penalaran (Kusumadewi, 2010).

\section{METODE PENELITIAN}

Penelitian ini akan membahas mengenai perancangan Sistem monitoring dan control Kandang Ayam Berbasis IoT (Internet Of Things)

\subsection{Blok Diagram Sistem}

Sensor MQ137 dan DHT22 yang terdapat pada kandang ayam itu lah yang mengirimkan data gas ammonia, suhu dan kelembaban pada kandang ayam. Dibantu nantinya NodeMCU esp8266 sebagai penghubung sensor dengan database sehingga data yang di keluarkan dapat lancer dan akurat sehingga tidak ada kekeliruan dalam data yang muncul di website penernak. menunjukkan bahwa data masukan berupa nilai yang terdapat sensor gas ammonia dan sensor DHT22, dimana terdapat juga keterangan yang dapat memudahkan peternak dalam membaca kadar gas ammonia, suhu dan kelembaban pada kandang ayam. Adapun blog diagram pada sistem ini, seperti ditunjukkan pada Gambar 5

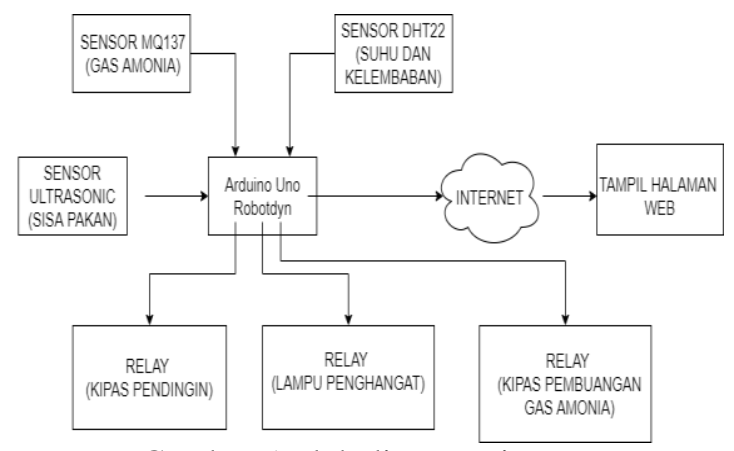

Gambar 5 Blok diagram sistem

\subsection{2 Flowchart Fuzzy Untuk Sensor suhu dan kelembaban}

Flowchart sistem ini menjelaskan proses berjalananya aplikasi seperti ditunjukkan pada Gambar 6

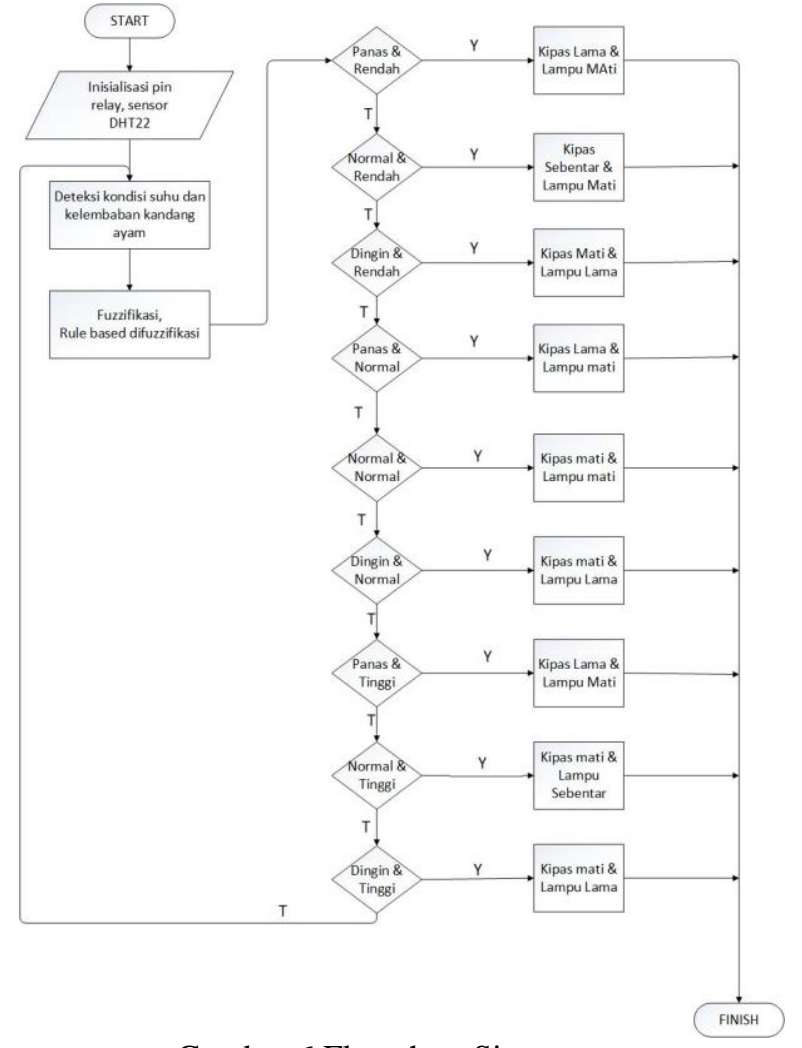

Gambar 6 Flowchart Sistem

Pada gambar 6 merupakan alur kerja dari logika fuzzy. Dimulai dari penginisialisasian pin relay dan sensor DHT22 kemudian mendeteksi suhu dan kelembaban oleh sensor DHT22, dilanjutkan proses fuzzifikasi, rule based, dan defuzzifikasi. Ada 4 kondisi yang akan didapatkan dari proses fuzzy. Pada kondisi suhu panas dan kelembaban rendah maka kipas Lama dan lampu Mati, suhu normal dan kelembaban rendah maka kipas Sebentar dan lampu Mati, suhu dingin dan kelembaban rendah maka kipas Mati dan lampu Lama, jika suhu panas dan kelembaban normal maka kipas Lama dan lampu Mati, jika suhu normal dan kelembaban normal maka kipas Mati dan lampu Mati, jika suhu dingin dan kelembaban normal maka kipas ati dan lampu Lama, jika suhu panas dan kelembaban tinggi maka kipas Mati dan lampu Lama, jika suhu normal dan kelembaban tinggi maka kipas Mati dan lampu Sebentar, jika suhu dingin dan kelembaban tinggi maka kipas Mati dan lampu Lama.

\subsection{Flowchart Fuzzy Untuk MQ137}

Pada gambar 7 merupakan alur kerja dari logika fuzzy. Dimulai dari penginisialisasian pin relay dan sensor MQ137 kemudian mendeteksi kadar gas amonia oleh sensor MQ137, dilanjutkan proses fuzzifikasi, rule based, dan defuzzifikasi. Ada 4 kondisi yang akan didapatkan dari proses fuzzy. Pada kondisi gas amonia sedang maka kipas hidup sedang. Gas ammonia tinggi maka kipas hidup kencang, gas ammonia normal maka kipas mati, dan ketijka gas ammonia rendah maka kipas akan hidup pelan. 


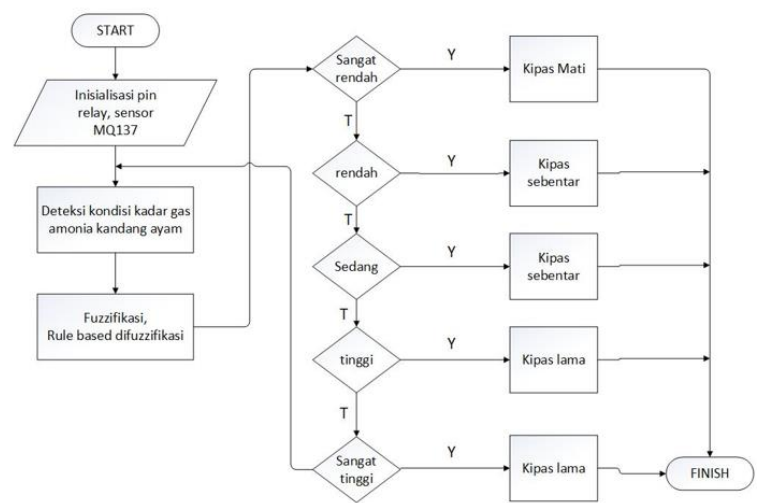

Gambar 7. Flowchart Fuzzy MQ137

\subsection{Flowchart Sistem}

Adapun alur proses system dijelaskan pada gambar 8 Pertama sensor MQ137 mendeteksi gas ammonia pada kandang ayam, kemudian sensor DHT22 mendeteksi suhu dan kelembaban pada kandang ayam. Setelah itu data dari sensor tersimpan ke database website dengan bantuan NodeMCU esp8266 agar datanya akurat dan lancar, yang akan dumunculkan di website.

Selanjutnya setelah data muncul ke layar website ketika suhu, kelembaban dan gas ammonia berada di bawah ambang batas maka keterangan akan berubah. Dan penernak bisa melihat kandang dalam kondisi normal atau tidak.

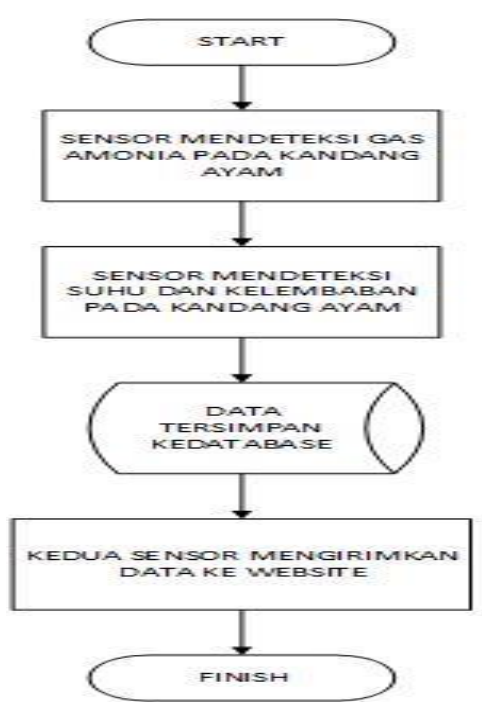

Gambar 8. Alur Proses Sistem

\subsection{Flowchat Alat}

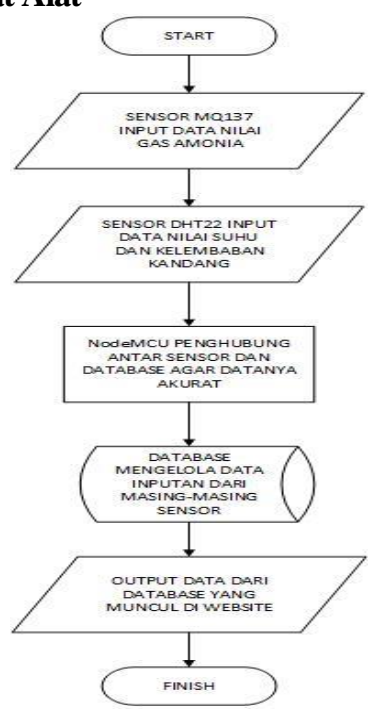

Gambar 9 Alur Proses Alat

Pertama sensor menginputkan varibel nilai gas ammonia dan variable suhu beserta kelembbabannya, kemudian dibantu oleh NodeMCU esp8266 sebagai penghubung proses pengiriman data kedalam database agar tersimpan datanya sebagai arsip, setelah masuk kedalam databse, datanya akan dikeluarkan ke tampilan website.

Penernak dapat memonitoring datanya secara realtime dan peternak dapat mengetahui dengan cepat kondisi kandang tampa harus kekandang, yang muncul pada keterangan, apakah kandang dalam keadaan normal atau tidak.

\subsection{Prototipe Desain Alat}

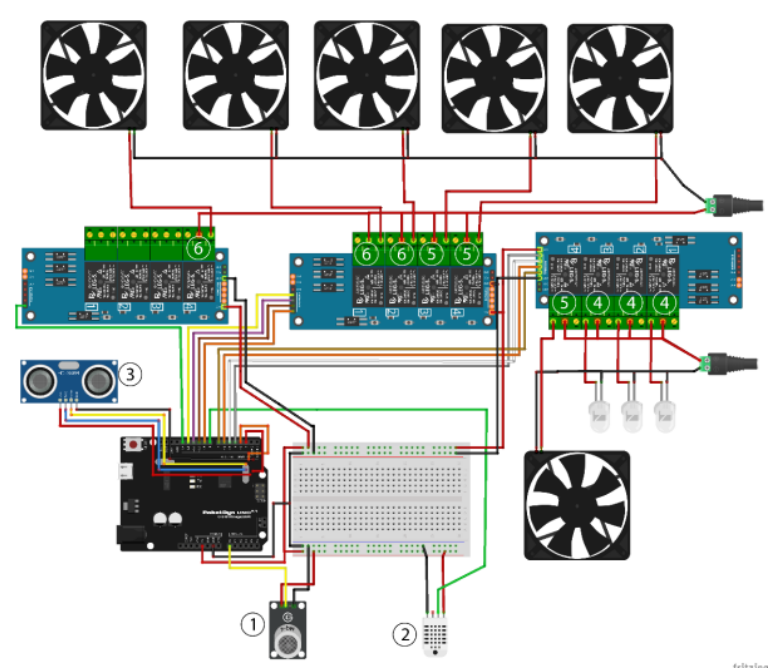

Gambar 10 Rangkaian Prototipe Desain Alat 
Gambar 10 merupakan skema rangkaian alat secara keseluruhan dari sistem monitoring terhadap IoT kandang ayak yang terdiri dari arduino uno sebagai mikrokontroler, Sensor MQ137 untuk mendeteksi gas amonia, sensor DHT22 untuk mendeteksi suhu dan kelembaban, Sensor ultrasonic untuk mendeteksi pakan ayam, kipas, lampu dan wifi ESP8266 sebagai perantara mengirim ke internet. Untuk kipas gas amonia mengarah keluar sedangkan kipas pendingin mengarah kedalam.

\section{HASIL DAN PEMBAHASAN}

Pada bab ini akan ditunjukkan hasil dan pembahasan terhadap proses yang telah dilakukan.

\subsection{Pengujian Sensor MQ137}

Tabel 4.1 Pengujian MQ137
\begin{tabular}{|c|c|c|c|}
\hline No & $\begin{array}{c}\text { Waktu } \\
\text { (detik) }\end{array}$ & $\begin{array}{c}\text { Sensor MQ } \\
137\end{array}$ & $\begin{array}{c}\text { Sensor MQ } 137 \\
\text { +Amonium hidroksida }\end{array}$ \\
\hline 1 & 10 detik & $0,03 \mathrm{ppm}$ & $155,94 \mathrm{ppm}$ \\
\hline 2 & 15 detik & $0,03 \mathrm{ppm}$ & $257,47 \mathrm{ppm}$ \\
\hline 3 & 20 detik & $0,02 \mathrm{ppm}$ & $328,23 \mathrm{ppm}$ \\
\hline 4 & 25 detik & $0,02 \mathrm{ppm}$ & $375,21 \mathrm{ppm}$ \\
\hline 5 & 30 detik & $0,03 \mathrm{ppm}$ & $397,62 \mathrm{ppm}$ \\
\hline
\end{tabular}

\subsection{Pengujian Sensor DHT22}

Dilakukan pengujian suhu dan kelembaban untuk sensor DHT22. Berikut hasil dari pengujian sensor suhu dan kelembaban menggunakan air panas.

Tabel 4.2 Pengujian Suhu

\begin{tabular}{|l|c|c|c|c|c|}
\hline No & $\begin{array}{c}\text { Waktu } \\
\text { (Jam) }\end{array}$ & Sensor Htc 2 & $\begin{array}{c}\text { Sensor } \\
\text { DHT22 }\end{array}$ & Selisih & $\begin{array}{c}\text { persentase } \\
\text { error }\end{array}$ \\
\hline 1 & $07: 46$ & $23,07{ }^{\circ} \mathrm{C}$ & $24,60^{\circ} \mathrm{C}$ & $1,53^{\circ} \mathrm{C}$ & $0,05 \%$ \\
\hline 2 & $08: 26$ & $25,00{ }^{\circ} \mathrm{C}$ & $26,00^{\circ} \mathrm{C}$ & $1{ }^{\circ} \mathrm{C}$ & $0,04 \%$ \\
\hline 3 & $10: 30$ & $26,01{ }^{\circ} \mathrm{C}$ & $26,70{ }^{\circ} \mathrm{C}$ & $0,69^{\circ} \mathrm{C}$ & $0,02 \%$ \\
\hline 4 & $11: 01$ & $26,00{ }^{\circ} \mathrm{C}$ & $26,30^{\circ} \mathrm{C}$ & $0,3^{\circ} \mathrm{C}$ & $0,01 \%$ \\
\hline 5 & $11: 35$ & $27,01{ }^{\circ} \mathrm{C}$ & $27,90^{\circ} \mathrm{C}$ & $0,89^{\circ} \mathrm{C}$ & $0,03 \%$ \\
\hline & \multicolumn{5}{|c|}{ Rata-rata persentase error } \\
\hline
\end{tabular}

Hasil dari pengujian sensor suhu dengan pengujian sensor bahwa nilai sensor saat diuji dalam 20 detik suhu dht berada pada $25.60{ }^{\circ} \mathrm{C}$ dan ketika ditambahkan uap air panas berada pada $26.50{ }^{\circ} \mathrm{C}$, dalam 40 detik suhu dht berada pada $26.40{ }^{\circ} \mathrm{C}$ dan ketika ditambahkan uap air panas berada pada 28.50 ${ }^{\circ} \mathrm{C}$, dalam 60 detik suhu dht berada pada $26.50{ }^{\circ} \mathrm{C}$ dan ketika ditambahkan uap air panas berada pada $29.50{ }^{\circ} \mathrm{C}$, dalam 80 detik suhu dht berada pada 26.50 ${ }^{\circ} \mathrm{C}$ dan ketika ditambahkan uap air panas berada pada $29.60{ }^{\circ} \mathrm{C}$, dalam 100 detik suhu dht berada pada 26.40 ${ }^{\circ} \mathrm{C}$ dan ketika ditambahkan uap air panas berada pada $29.80^{\circ} \mathrm{C}$

Tabel 4.3 Pengujian kelembaban
\begin{tabular}{|c|c|c|c|c|c|}
\hline No & $\begin{array}{c}\text { Waktu } \\
(\mathrm{Jam})\end{array}$ & $\begin{array}{c}\text { Sensor } \\
\text { Htc } 2\end{array}$ & $\begin{array}{c}\text { Sensor } \\
\text { DHT22 }\end{array}$ & selisin & $\begin{array}{c}\text { persentas } \\
\text { e error }\end{array}$ \\
\hline 1 & $07: 46$ & $87 \%$ & $88,50 \%$ & $1,5 \%$ & $0,01 \%$ \\
\hline 2 & $08: 26$ & $85 \%$ & $98,30 \%$ & $13,3 \%$ & $0,15 \%$ \\
\hline 3 & $10: 30$ & $84 \%$ & $99,10 \%$ & $15,1 \%$ & $0,17 \%$ \\
\hline 4 & $11: 01$ & $84 \%$ & $99,30 \%$ & $15,3 \%$ & $0,18 \%$ \\
\hline 5 & $11: 35$ & $82 \%$ & $97,40 \%$ & $15,4 \%$ & $0,18 \%$ \\
\hline \multicolumn{7}{|c|}{ Rata-rata persentase error } & & $0,13 \%$ \\
\hline
\end{tabular}

Hasil dari pengujian sensor suhu dengan pengujian sensor bahwa nilai sensor saat diuji dalam 2 detik suhu dht berada pada 97.20 \% dan ketika ditambahkan uap air panas berada pada $99.0 \%$, dalam 4 detik suhu dht berada pada $98.10 \%$ dan ketika ditambahkan uap air panas berada pada 99.10 $\%$, dalam 6 detik suhu dht berada pada $98.40 \%$ dan ketika ditambahkan uap air panas berada pada 99.20 $\%$, dalam 8 detik suhu dht berada pada $99.00 \%$ dan ketika ditambahkan uap air panas berada pada 99.30 $\%$, dalam 10 detik suhu dht berada pada $98.90 \%$ dan ketika ditambahkan uap air panas berada pada 99.90 $\%$.

\subsection{Pengujian Sensor Ultrasonik}

Pengujian sensor ultrasonik dilakukan dengan membandingkan keluaran sensor ultrasonik dengan alat ukur penggaris, seperti terlihat pada tabel:

abel 4.4 Pengujian jarak sensor ultrasonik

\begin{tabular}{|c|c|c|c|c|}
\hline No & Penggaris & Sensor ultrasonik & selisih & Persentase error \\
\hline 1 & $5 \mathrm{~cm}$ & $4,75 \mathrm{~cm}$ & $0,85 \mathrm{~cm}$ & $0,17 \%$ \\
\hline 2 & $10 \mathrm{~cm}$ & $9,09 \mathrm{~cm}$ & $0,91 \mathrm{~cm}$ & $0,09 \%$ \\
\hline 3 & $15 \mathrm{~cm}$ & $13,91 \mathrm{~cm}$ & $1,09 \mathrm{~cm}$ & $0,07 \%$ \\
\hline 4 & $20 \mathrm{~cm}$ & $18,83 \mathrm{~cm}$ & $1,17 \mathrm{~cm}$ & $0,05 \%$ \\
\hline 5 & $25 \mathrm{~cm}$ & $23,51 \mathrm{~cm}$ & $1,49 \mathrm{~cm}$ & $0,05 \%$ \\
\hline \multicolumn{4}{|c|}{ Rata-rata persentase error } & $0,08 \%$ \\
\hline
\end{tabular}

\subsection{Pengujian Software}

Uji perangkat lunak dalam penelitian ini dengan menguji kompatibilitas situs web terhadap browser web yang bertujuan untuk mengetahui apakah halaman website yang dibuat dapat menampilkan keseluruhan data sesuai dengan perancangan bukan hanya pada satu web browser yang sering digunakan pada umumnya.

\begin{tabular}{|c|c|c|c|c|c|}
\hline \multirow[b]{2}{*}{$\begin{array}{r}\mathrm{N} \\
\mathrm{O}\end{array}$} & \multirow[b]{2}{*}{$\begin{array}{c}\text { Aspek } \\
\text { Pengujian }\end{array}$} & \multicolumn{4}{|c|}{ Web Browser } \\
\hline & & $\begin{array}{c}\text { Firefo } \\
\mathrm{x} \\
\text { versio } \\
\mathrm{n} \\
84.0 .2\end{array}$ & $\begin{array}{c}\text { Brave } \\
\text { version } \\
88.1 .19 .86\end{array}$ & $\begin{array}{c}\text { Microsoft } \\
\text { Edge version } \\
87.0 .664 .75\end{array}$ & $\begin{array}{c}\text { Google Chrome } \\
\text { version } \\
87.0 .4280 .141\end{array}$ \\
\hline 1 & $\begin{array}{c}\text { Fungsi } \\
\text { Login }\end{array}$ & $\checkmark$ & $\checkmark$ & $\checkmark$ & $\checkmark$ \\
\hline 2 & $\begin{array}{l}\text { Halaman } \\
\text { Monitoring }\end{array}$ & $\checkmark$ & $\checkmark$ & $\checkmark$ & $\checkmark$ \\
\hline 3 & Responsive & $\mathrm{x}$ & $\mathrm{x}$ & $\mathrm{x}$ & $\mathrm{x}$ \\
\hline
\end{tabular}

Keterangan:

$$
\begin{aligned}
& \checkmark \text { : Berhasil } \\
& \mathrm{x}: \text { Tidak Berhasil }
\end{aligned}
$$


Dapat dilihat hasil uji coba pada tabel 4.4 bahwa aplikasi yang dibuat dapat berjalan dengan baik pada web browser Firefox , brave dan Microsoft Edge yaitu tampilan login dan semua fungsi di halaman utama dan tampilan logout berfungsi dengan baik.

\section{KESIMPULAN DAN SARAN}

\subsection{Kesimpulan}

Berdasarkan beberapa pengujian yang telah dilakukan didapatkan kesimpulan :

1. Sistem yang dibuat merupakan sistem monitoring dan kontrol suhu, kelembaban, gas ammonia dan sisa pakan pada kandang ayam. Yang diletakan pada source code Arduino, yang akan mengeluarkan output sesuai dengan aturan atau rule yang sudah ditentukan. Kebutuhan pada produk skripsi yang dikembangkan mencakup sensor DHT22 untuk mendeteksi suhu dan kelembaban, sensor MQ 137 untuk mendeteksi gas amonia, dan sensor ultrasonik digunakan untuk mendeteksi sisa pakan ayam.

2. Penerapan metode fuzzy mamdani pada sistem kontrol otomatis suhu, kelembaban, dan gas amonia yang diterapkan pada source code arduino. Yang dapat dimonitoring pada website dengan Firefox version 84.0.2, Brave version 88.1.19.86, Google Chrome version 87.0.4280.141 dan Microsoft Edge version 87.0.664.75 dengan tampilan login dan semua fungsi di halaman utama dan tampilan logout berfungsi dengan baik. Dari pengujian sistem dapat berjalan dengan baik menggunakan bahasa pemrograman PHP, MySQL sebagai database Dari pengujian sensor rata-rata presentase error pada sensor suhu 0,03\%, sensor kelembaban $0,13 \%$ dan sensor ultrasonic $0,08 \%$ Sensor mq137 dapat mendeteksi gas ammonia dengan baik sesuai dengan real time yakni $100 \%$

\subsection{Saran}

Berdasarkan penelitian yang telah dilakukan, maka penulis dapat memberikan saran-saran untuk pengembangan selanjutnya antar lain :

1. Memberikan notifikasi berupa email apabila terdeteksi kondisi pasien sedang kritis.

2. Pemilihan sensor-sensor yang tepat untuk dikembangkan.

3. Untuk pengembangan kedepannya ditambahkan untuk pemberian pakan secara otomatis.

4. Untuk pengujian gas ammonia menggunakan alat yang sudah jadi sehingga memperoleh perbandiangan data antara sensor MQ137 dengan alat.

5. Untuk memonitorng bisa dikembangkan menjadi aplikasi android dengan tambilan yang lebih mudah, efektif dan efesien.

\section{DAFTAR PUSTAKA}

[1] Andani, S.R., 2015, July. Fuzzy Mamdani Dalam Menentukan Tingkat Keberhasilan Dosen Mengajar. In Seminar Nasional Informatika (SEMNASIF) (Vol. 1, No. 4).

[2] Kurnia, D. and Hadisantoso, F.S., 2017. Rancang Bangun Sistem Otomasi Peternakan Ayam Berbasis Arduino R3 di Cikalong Wetan. Jurnal Elektra, 2(1), pp.58-64.

[3] Cahyono, A.T.C.A.T. and Priambodo, F.A., 2014. Purwarupa Blower Otomatis Untuk Mengeluarkan Gas Amonia Berbahaya Pada Kandang Ayam Broiler Berbasis Mikrokontroler Atmega 16 (Doctoral dissertation, Universitas Kanjuruhan Malang).

[4] Maghfiroh, N.A., 2017. Efektivitas sistem informasi pelaporan monitoring dan evaluasi (econtrolling) pada bagian evaluasi pembangunan sekretariat daerah kota bontang. Jurnal Paradigma (JP), 5(1), pp.34-44.

[5] Priyanto, W., Nugroho, D. and Widada, B., 2015. Sistem Informasi Monitoring Perkuliahan Berbasis Web Di STMIK Sinar Nusantara Surakarta. Jurnal Teknologi Informasi dan Komunikasi (TIKomSiN), 3(1).

[6] Dedy Irawan, J., Handoko, F. and Adriantatri, E., 2019. Ruang Kuliah Pintar Pemantau Tingkat Efektivitas Pembelajaran Yang Dapat Mendeteksi Mahasiswa Bosan Dan Mengantuk. In Seminar Nasional Inovasi dan Aplikasi Teknologi di Industri.

[7] Risnandar, E., 2015. Pembuatan Aplikasi Sistem Informasi Monitoring Kegiatan Mahasiswa Berbasis Web dan Android Client (Doctoral dissertation, UNIVERSITAS NEGERI SEMARANG).

[8] Heriawan, R., Suciyati, S.W. and Supriyanto, A., 2013. Alat Pengontrol Emisi Gas Amonia (NH3) di Peternakan Ayam Berbasis Mikrokontroler ATMega 8535 Menggunakan Sensor Gas MQ-137. Jurnal Teori dan Aplikasi Fisika, 1(1).

[9] Elang, S., 2015. "Cara Kerja Sensor Ultrasonik, Rangkaian, \& Aplikasinya" e-book, Accessed September 2020

[10] Dewaweb, 2018 "Internet of Things: Panduan Lengkap" e-book, Accessed September 2020

[11] AMRULLAH, N.A., 2017. Alat Kontrol Suhu dan Kelembaban Otomatis pada Ruang Budidaya Jamur Tiram Berbasis ATmega32 (Doctoral dissertation, UNIVERSITAS 17 AGUSTUS 1945 SURABAYA).

[12] Kho, D., 2015. "Pengertian relay dan fungsinya. Teknik Elektronika, Maret". e-book, Accessed September 2020 